常に高率であった，性差においては，30３9才を除き女 性の方が高率であった。０～9才の若年者から発現は高 率で，20〜29才でピークを示した後，30才より減少する が，男性は40才以後急減する，女性沉おいては40４9才 で再び上昇を示し，50才以後減少する.

2. 歯牙別にみた発現部位は，前歯部52～64\%，犬雬 部33〜50\%，小曰菊部 $41 \sim 53 \%$, 大田歯部 $23 \%$ 以下で, 前㦱より後方歯におよぶにしたがい，その程度を減ず る．側切歯を中心とした前後がもっとも高率である，下 顎に比し上顎が高率である，側別をみると下䅡の場合， 右側の方が高率である。

3. 顎全体についてみると，男女とも，全類にあらわ れるものが最も多く，男性 $48.5 \%$ ，女性 $34.5 \%$ である。

4. 沈着形態は, 男女とも, 全顎にあらわれるもの は, 境界鮮明な, band 型, 次に triangle 型がしめた。 質 問 池 尻 (2口外)

1. 画肉の色素沈着と皮虞症状は平行して現われるか.

2. vermilion border の不鮮明になる例はなかったか. 応 答 六反田 (解 剖)

1. 平行して現われる例が多いと思う。

2. 同系統の色のために不鮮明にみられる例はあった。 質 問 田緣 昭 (熊大・歯)

診查された地域の正常者の色素沈着について検討され たか．安藤の成績と単純に比較することは問題があるよ うに思う。 P C Bの場合は，単純に対称をえらび，それ を正常者と判断するととはむずかしいと思う。

応 答 六反田 (解 剖)

P C B は新環境污染物質であり, 全世界の生物に P C $\mathrm{B}$ は蓄積されていると思うので, 対称の元らび方は非常 にむずかしく，逆に単純に同地域を対称とえらぶのは問 題がある。

\section{2.癌治㞠における放射線增感剮の影響に関する実験的 研究}

$$
\text { 右田秀信・古本克磨・池尻 茂 (2口外) }
$$$$
\text { 大庭 健・佐藤信正（雬放射） }
$$

放射線増感剤， B n d R t応用した放射線療法におけ る治療効果について， $\mathrm{VX}_{2}$ 癌を使用し，実験を行なっ た. $\mathrm{VX}_{2}$ 癌を家鬼下腿皮下移植後, 小指頭大に增大し た 1 週間目に実験群として, B n d R $50 \mathrm{mg} / \mathrm{kg} 5$ - F n

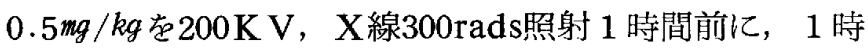
間から 1 時間30分かけて点滴動注した。乙の操作を 5 日 間連日行ない総線量1500radsとした．対照群にはX線照 射単独, 及び，無処置群を行なった。そ結果，実験群
では治療後21日前後で, 経皮的に腫㾍を触知不可能なほ ぞ縮少した。また，組織的に観察すると，腫瘍細胞の著 しい膨化，核の萎縮，濃染，さらには消失などの明瞭な 久落像がみられ，肉眼的にも，組織的にも優れた治療効 果が得られた。 またX線単独照射群と比較して有意の結 果が得られた。 今後さらに放射線療法におりる治療過程 の経日的観察と，より長期の実験例を加え詳細任追求す る尒定である。
質 問
伊 藤（長大・柬）

1. 臨床的に使用経験があったら，その成果と奏験的成 果は同じか.

2. 放射線増感凨と考えてよいか. 灾 答 右 田（2口外）

1. 臨床的に使用した経験はない。

2. 放射線増感凰である.

\section{3. 口腔領域における精神身体症とその症例について} 尾 崎 安 彦 (九州心身医)

(1) 研究目的

精神身体症は心身症ともいはれている．現代医学は科 学的な実験研究による警異的な発展と共に, 人類えの偉 大な貢献がなされたのであるが，その反面心理的な側面 は軽視されがちであることに注目された。そてで真に人 問的な医療を開発し，推進するためには，人間性の尊重 と共に心身相関に対しての科学的な追求と深い患者理解 が強張され，心身医学が発達した。そてで歯科における 心身症に注目し症例老追求した。

(2) 方法

身体面の徹底した検查，心理面の検査，面接による心 理㙩法, 向精神薬, 自律訓練法, 催眠療法, 行動療法等 を症例により応用する。

(3) 成績
今回提出した症例
（1）は好結果が出た，症例
(2) は 精神病と神経症とのボーダーラインにあると思はれたの で，専門医に転送した。

(4) 結論

症例(1)の歯ぎしりは, 自律神経の一過性の調節機能の 失調といわれているので，適切な催眠暗示により著効が あったと思われる。症例(2) Polysurgeryは，マゾヒズム 的傾向があるために現実からの逃避や，莫藤からの回避 といわれている。その症状は転々と痛みを訴える部位が 変っていく，いわゆる syndrome schift を起てし, 夜 は異常な痛みの訴えと共に街を彷得し, 昼間は比較的に 痛みを訴えないといった異常な問題点がある。このよう 
な症例に対しては，心身医学を研究した菌科殹に送り， 心身両面からの治療をす心゙きであろう。な技難症につい ては，神経内科，精神科等え直送すべきである。

質 間

前川（長大・医，歯）

Polyserqery の患者は教室でもそう遇するが，医師え の不信感によって起てるととが多いようで，心身医療法 を教へて下さい。

応 答

尾 崎 (儿州心身医研)

1. Polyserqery の診断 既往症を問診によって十分に たずねる。

2. 医師えの不信感については，心身医学的面接法伅よ り解決できる。

3. 謬断としては， $1 ， 2$ を参考にして心理テスト，生 理的検查法等により磪診する.

4. 療法

面接法，向精神薬，ソーシャル・ケースワーク，自 律訓練法, 催眠療法, 行動療法等以上を適宜に組合せ る.ボーダラインケースについては，尃門医えの転送 が望ましい。

\section{4. ラット臼歯の上皮遺残の分布及び形態学的変化につ いて}

○秋満綱幸・上野正康（口 病）

（目的）雬根膜腔に存在するマラッセ上皮遺残は，胎生 期的なへルトウィッ上上皮鞘が寸断されて残存せる上支 細胞群であるが，従来より乙れに関する研究は，主とし て発生学的検索に主眼がむけられていて，加令的に辿る 変化についての研究は少ない，われわれはラット曰茵茵 根膜の上皮遗残について, 発生加ら加令的に起こる変化 を検索しているので今日までに得た結果をのべる。（材 料と方法）材料にはラット臼霜をえらび今回は主に生後 1 日目から 100日 までについて, 上皮遺残の発生と加令 によって起てる上皮遺残の分布様相や形態的変化を詳細 に検索し，100日以後については若干の例を検索した。

(結果) 1. ラット曰雨の咬頭頂にはエナメル質は形成 されないで萌出前に焧頭頂にあたる部のエナメル上皮は 重風扁平上皮化生を起乙す。その時，乙の部に成書に記 載されているへルトウィッ七上皮䩗が寸断されていく過 程において みられる網眼構造に類似せる所見がみられ

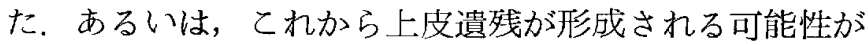
あるのかもしれないので, 乙の点は今後いっそう追求し てみたい．2. ラット臼菌の上皮遗残は，根側中央部お よび根分岐部にもっともよくみられる，3. 上皮遺残 は，発生初期には，小さく，乙れを形成する個々の細胞
も小さいが，生後50日頃から大きな上遗残がしばしば みられるようになり，さらに経日的に個々の細胞も大型 化している，4.上皮遺残は上下顎とも，ほぼ生後30日 目以後にみられるようになり, 生後 100日までの上皮遺 残の分布量は生後45日から70日頃までもっとも豊富であ $っ て$, 以後は若干減少していく，5. 生後 500 日以後の 例には，しばしば上皮遺残が石灰化しているものがみら れたが，発生から，てのように石灰化していくまでに辿 る. 形態学的变化については, 生後 100 日目以後の例数 を增やして経日的に，さらに詳細に迫求していくつもり である。

\section{Betatron 電子線局部照射による幼若犬の永久菌菌 肧を含む下顎骨に及ぼす彰響に関する実験的研究（第 一報）}

$$
\text { 。福田仁一・山田長敬 (1口外) }
$$

近年，顎・口腔領域の腫瘍に対する放射線治潦に電子 線が良く使われる．これは，電子線が表風〜中層の腫瘍 に適しているてと，照射後の組織の回復が早いことなど からである，しかし，小贸の腫瘍に対する放射線の影響 は，今後の発育に多くの問題を残す。

そてで, 私は, 幼犬の菌胚を中心に電子線を照射し， 照射後の曾臕およびその周冊組織がいかなる変化を起こ すかという研究を行なった，乙れは，その第一報，X線 学的所見である。

動物は生後約 3 力月の幼犬を用い，島津製作所製 BT $20 \mathrm{~A}$ ベータトロンを使用し, 右側下枵第 3 乳臼菌, およ び第 4 小曰歯歯胚に， $4 \mathrm{MeV} ， 2 \mathrm{~cm} \varnothing$ の照射筒を使っ て，1200Rの 1 回照射を行なった。なお，対照群は，同 一犬の反対側同部位在用いた。照射後, 経日的に屠殺 し，軟X線撮影を行ない観察した。

肉腿的所見：照射後14日目頃より，照射部皮膚の脱毛 が起こり，照射後30日目には完全に脱毛し，照射後60日 目頃から再び発毛がはじまる。

軟X線所見：照射後 $1 \sim 7$ 日日までは著変は認められ ない，照射後10日目に，歯根形成部尖端が内側に彎曲し た所見がみられる。その他著変は認められない，その 後, 彎曲部は $14 ， 21$ 日になるにしたがい，顕著になる。 照射後30日目に根分岐部の硬組織形成が見られるように なる．根分岐部も対照側に較べ，根離開が大きくなって いる，照射後60日目には，霜根形成が著明となるが，実 験側は，尖端が丸味を带び，根の愊が狭くなっている。 照射後90日目には，対照側は完全に萌出しているのに対 し，実験例は中央咬頭のみ萌出している。 また，根は非 